\title{
Toxicological Study of a Siddha Sastric Formulation Arumuga Chendhuram in Rat Model
}

\author{
Ramamurthy Murugan ${ }^{1 *}$, Thanigavelan $\mathrm{Vembu}^{2}$, Manickavasakam Kumarswamy ${ }^{3}$ \\ ${ }^{1}$ Department of Noi Naadal (Siddha Pathology), National Institute of Siddha, Chennai, Tamil Nadu, India. ${ }^{2}$ Department of Gunapadam, Sri Sairam Siddha \\ Medical College and Research Centre, Chennai, Tamil Nadu, India. ${ }^{3}$ Former Director, National Institute of Siddha, Chennai, Tamil Nadu, India.
}

\begin{tabular}{l} 
ARTICLE INFO \\
\hline Article history: \\
Received on: $28 / 12 / 2015$ \\
Revised on: $18 / 01 / 2016$ \\
Accepted on: $21 / 02 / 2016$ \\
Available online: $30 / 03 / 2016$ \\
\hline Key words: \\
Siddha, Chendhuram, Acute \\
Toxicity, Subacute Toxicity, \\
Arumuga Chendhuram.
\end{tabular}

\begin{abstract}
The study was aimed to profile the acute and sub-acute oral toxicity of a herbo-metallic drug Arumuga Chendhuram (AC). AC was prepared classically and analyzed for elemental composition using X-ray Fluorescence. Acute oral toxicity study was done on female rats at $\mathrm{AC} 2 \mathrm{~g} / \mathrm{kg}$ as single administration following OECD guideline 423. For sub acute toxicity study, AC was administered orally for 28 consecutive days suspended in vehicle (Honey + distilled water) to rats following OECD guideline 407. Four groups was allotted (10 rats/group), control received vehicle; the other received AC at 12, $24 \& 48 \mathrm{mg} / \mathrm{kg} / \mathrm{day}$ respectively. Mortality and abnormal clinical signs were observed. Haematological and biochemical parameters were analyzed using auto analyzer with standard kits and ANOVA-Dunnett test was performed for significant analyses. Gross necropsy and histopathology studies using H\&E stain were done on major organs. Mercury and Lead were found more than the WHO permissible limits in XRF study. LD50 was found more than $2 \mathrm{~g} / \mathrm{kg}$. NoObserved-Adverse-Effect level of AC was seen at $24 \mathrm{mg} / \mathrm{kg}$ in 28 days of treatment. No abnormal findings were noted in high dose group organs. Administration of AC at its human therapeutic dose of $260 \mathrm{mg} / \mathrm{kg}$ in rat (24 $\mathrm{mg} / \mathrm{kg}$ ) is safe.
\end{abstract}

\section{INTRODUCTION}

Among the thirty two types of pharmaceutical forms administered as internal medicines mentioned in the Siddha literature, Chendhuram (Red oxide form) plays an important role in treating chronic ailments. It can be prepared by making metallic salts or arsenical compounds into reddish fine powders by the process of burning, frying, calcinating or grinding along with herbal juices or ceyaneers (Anaivaari, 2008). Arumuga Chenduram (AC) is a herbo-metallic Siddha medicinal formulation commonly used in the practice having a spectrum of therapeutic indications such as Araivatham (Inguinal Hernia), Kudalvatham, Viraivatham (Scrotal Swelling), Eruvai mulai Noi (Anorectal disorders), Erikunmam (Gastric inflammation), Pandu (Anaemia), Sobai (Anasarca), Kiranthi (nodules), Araiappu (Buboes), Kandamalai (Cervical adenitis) and Soolai (Throbbing pains) at the dosage of $260 \mathrm{mg} / 70 \mathrm{~kg} /$ day (Kuppusamy, 1998). $\mathrm{AC}$ is processed by burning the ingredients Valairasam

* Corresponding Author

Ramamurthy Murugan, Department of Noi Naadal (Pathology), National Institute of Siddha, Chennai, India. Email: ramsnis[at]gmail.com
(Sublimated Mercury), purified forms of Ayam (Iron ores), Kaantham (Magnetite/Load stone), Gandhagam (Sulphur), Venkaaram (Borax) and Indhuppu (Rock salt) along with herbal juice of Sotru Katraazhai (Aloe vera). During the process of AC preparation, the metallic ingredients added were in elemental form but after the process, the elements were converted into compound oxide forms. The presence of free elemental form of metals in the drugs if and when administered, accumulates in soft tissues and proves to be toxic for body systems (Kapoor, 2010). The present study investigated the metallic concentrations found in the AC and its acute and sub acute oral toxicity profile in rat.

\section{MATERIALS AND METHODS}

\section{Preparation of test drug Arumuga Chendhuram}

The ingredients such as Valai Rasam (Sublimated Mercury-Purest form of Mercury), purified Kaantham (Magnetite), purified Gandhagam (Sulphur), purified Venkaaram (Sodium biborate-Borax), purified Indhuppu (Rock salt), purified Ayam powdered (Ferrum-Iron) procured from registered Siddha Medical practitioner Dr. Murugesan MD Siddha, Orathanadu, Tamilnadu. 
The plant material Sotru Katraazhai (Aloe vera) was collected from the herbal garden of National Institute of Siddha, Chennai and was authenticated (Specimen Voucher No.NIS/MB/97/2013) by the botanist, National Institute of Siddha, Chennai-47. Arumuga Chendhuram (AC) was prepared using the above ingredients by strictly following the classical Calcination process mentioned in Siddha Vaithiya Thirattu (Kuppusamy, 1998).

\section{Quantitative analysis of test drug}

The elemental concentration in $\mathrm{AC}$ was estimated using X-ray fluorescence (XRF) spectrometer (Bruker S8 Tiger) operated in vacuum mode and followed the instruction mentioned in the manual of the instrument used. The elements in AC were analysed in two forms such as oxide and element form. This experiment was done at Centre for Advanced Research in Indian System of Medicine (CARISM), SASTRA University, Thanjavur, Tamil Nadu, India.

\section{Experimental Animals}

Healthy out bred Wistar Albino Rats of either sex weighing about 120 - $160 \mathrm{~g}$ were obtained from the Animal house of King Institute of Preventive Medicine and Research, Guindy, Chennai and maintained in the Animal house of National Institute of Siddha, Chennai. The female rats obtained were nulliparous and non pregnant. All the animals were properly maintained and strictly following the "Guidelines on care and maintenance of laboratory animals" that have been framed by the Committee for the Purpose of Control and Supervision of Experiments on Animals (CPCSEA), Ministry of Environment, Forests and Climate Changes, Government of India. The animals received RO water ad libitum and fed with Rodent pellet which was purchased from Shri Venkateshwara Traders, Bengaluru. Before the induction of toxicity study, all the animals were acclimatized for seven days. The study protocol has got approval from Institutional Animal Ethical Committee of National Institute of Siddha, Chennai (1248/ac/09/CPCSEA/5-12/2011).

\section{Acute toxicity Study}

This study was carried out by following the procedure with the starting dose of $2000 \mathrm{mg} / \mathrm{kg}$ body weight of test drug mentioned in OECD 423 guideline; six female rats were randomly selected and acclimatized prior to the study (OECD, 2000). Each selected animal was kept in separate poly propylene cage and marked with picric acid on the fur for identification. The rats were fasted overnight before the administering of test drug. After the administration of test drug, the rats were deprived of feed for $16 \mathrm{~h}$ and water was not allowed for initial $3 \mathrm{~h}$. The study was conducted initially with the starting dose of $2000 \mathrm{mg} / \mathrm{kg}$ administering in three rats and observed for mortality. As there was no mortality, three more rats were subjected to the study with the same dosage of test drug. The test drug AC was administered through oral gavage suspended in the mixture of honey $(1 \mathrm{ml})$ and distilled water $(1 \mathrm{ml})$ as single dose. The rats were observed for mortality, behavioural changes and clinical signs of toxicity for half an hour once of first four hours after dosing and thereafter periodically up to 14 days on same time of each day.

\section{Sub-acute toxicity study}

This study was carried out by following OECD guidelines adopted for the testing of chemicals -407 ( $3^{\text {rd }}$ October, 2008) and was modified according to the experimental need (OECD, 2008). In the literature Siddha Vaithiya Thirattu, the human intended dosage for $\mathrm{AC}$ was recommended as $130 \mathrm{mg}$ twice a day (260 mg/day) (Kuppusamy, 1998). On the basis of body surface area conversion against human dose, $24 \mathrm{mg} / \mathrm{kg} / \mathrm{day}$ dosage of AC was calculated for rat (Paget and Barnes, 1964). In the present study, three doses of AC of $12 \mathrm{mg} / \mathrm{kg} /$ day (Low dose), $24 \mathrm{mg} / \mathrm{kg} /$ day (Intermittent dose) and $48 \mathrm{mg} / \mathrm{kg} /$ day (High dose) were selected for administration.

The both sexes of Wistar Albino rats were randomized into four groups of ten animals each ( 5 males, 5 females). Group I received a vehicle (Honey $1 \mathrm{ml}+$ distilled water $1 \mathrm{ml}$ ) and served as control group. Group II, III and IV served as low, intermittent and high doses of AC respectively. All the test substances were administered once daily via oral route through gastric gavage for 28 days. All the rats were observed daily for mortality, morbidity and abnormal clinical signs on each day for the same time. The body weight change, water and food consumption of each rat was monitored once a week. At the end of the $28^{\text {th }}$ day of treatment, live rats were fasted over night and on the $29^{\text {th }}$ day under light chloroform anaesthesia, blood were drawn using capillary tube from the retro orbital sinus and added into a tube with potassium EDTA and a tube without anticoagulant.

The haematological parameter tests such as Haemoglobin (Hb), Red Blood Cell count (RBC), White Blood Cell count (WBC), WBC Differential count - Lymphocyte, Monocyte and Granulocyte, Red Cell Distribution Width (RDW), Haematocrit (HCT), Mean Corpuscular Volume (MCV), Mean Corpuscular Haemoglobin (MCH), Mean Corpuscular Hemoglobin Concentration (MCHC), Platelet (Plt), Platelet Crit (PCT), Platelet Distribution Width (PDW) and Mean Platelet Volume (MPV) were done in the EDTA mixed blood samples using Erba Mannhein ${ }^{\circledR}$ haematology analyser. The blood samples without anticoagulant were used for estimating biochemical parameters such as Glucose, Cholesterol, Triglyceride (TG), Protein, Urea, Creatinine, Bilirubin, Serum glutamic-oxaloacetic transaminase (SGOT), Serum glutamic pyruvic transaminase (SGPT) and Alkaline Phosphatase (ALP) using Erba system Pack kits in Fully Automated Biochemistry analyzer (Transasia EM 360). Sodium, Potassium and Chloride content were estimated by using electrolyte analyser from Roche ${ }^{\circledR}$.

After withdrawal of blood, all the rats were sacrificed for gross necropsy and histopathological study. Organs including brain, trachea, lungs, heart, liver, kidney, stomach, spleen, intestine, testis, seminal vesicle, bladder, uterus and ovaries were studied for gross necropsy and weighed for calculating relative organ weight. Histopathological studies on liver, kidney, lungs, 
stomach, heart, spleen, brain, and femorotibial joints were carried out for control and high dose group. The tissues of collected organs were fixed in $10 \%$ Neutral buffered formalin for $24 \mathrm{~h}$. The tissues were trimmed, embedded in molten paraffin wax and sectioned (4-5 microns thickness) using rotary microtome. The sections were floated in hot water and placed in the glass slide. The slides were stained with Haematoxylin and Eosin (H\&E), mounted in DPX and examined under light microscope (Singh and Sulochana, 1997)

\section{Statistical analysis}

All data were expressed as mean \pm standard deviation (SD). The test groups were compared with control group for testing significance and done by One-way Analysis of Variance (ANOVA) followed by Dunnett Multiple Comparisons Test using GRAPH PAD INSTAT version 3 software programs. Values of $\mathrm{p}<0.05$ were considered significant.

\section{RESULTS AND DISCUSSION}

Arumuga Chendhuram (AC) constitutes mineral ingredients such as purified Iron, Magnetic oxide of iron, Sulphur, Mercury, Sodium Impura and Borax which are known to be toxic during the process. An element which undergone oxidation process and form a compound does not produce toxicity in human. In the quantitative study of $\mathrm{AC}$ estimated through X-ray fluorescence spectroscopy study, it is inferred that the presence of metals are in compound oxide form such as Ferric oxide (44\%), Sulphur trioxide (18.5\%), Disodium oxide (17\%), Silicon dioxide (13\%) and the remaining were traces of other oxides (Table 1).

Table 1: Elemental concentration in Arumuga Chendhuram .

\begin{tabular}{cccc}
\hline \multicolumn{2}{c}{ Element in Oxide form } & \multicolumn{2}{c}{ Element form } \\
\hline \multirow{2}{*}{ Formula } & $\begin{array}{c}\text { Concentration } \\
(\boldsymbol{\%})\end{array}$ & Formula & $\begin{array}{c}\text { Concentration } \\
(\boldsymbol{\%})\end{array}$ \\
\hline $\mathrm{Fe} 2 \mathrm{O} 3$ & 44.33 & $\mathrm{Fe}$ & 67.92 \\
$\mathrm{SO} 3$ & 18.54 & $\mathrm{Na}$ & 12.58 \\
$\mathrm{Na} 2 \mathrm{O}$ & 16.95 & $\mathrm{~S}$ & 7.44 \\
$\mathrm{SiO} 2$ & 13.43 & $\mathrm{Si}$ & 6.28 \\
$\mathrm{Cl}$ & 3.83 & $\mathrm{Cl}$ & 3.83 \\
$\mathrm{~A} 2 \mathrm{O} 3$ & 0.83 & $\mathrm{Ca}$ & 0.48 \\
$\mathrm{CaO}$ & 0.67 & $\mathrm{Al}$ & 0.44 \\
$\mathrm{~K} 2 \mathrm{O}$ & 0.47 & $\mathrm{~K}$ & 0.39 \\
$\mathrm{MgO}$ & 0.44 & $\mathrm{Mg}$ & 0.26 \\
$\mathrm{MnO}$ & 0.16 & $\mathrm{Hg}$ & 0.13 \\
$\mathrm{Hg}$ & $\mathrm{Mn}$ & 0.12 \\
$\mathrm{P} 2 \mathrm{O} 5$ & 0.13 & $\mathrm{~Pb}$ & 0.05 \\
$\mathrm{PbO}$ & 0.08 & $\mathrm{P}$ & 0.04 \\
$\mathrm{CuO}$ & 0.05 & $\mathrm{Cu}$ & 0.04 \\
$\mathrm{Cr} 2 \mathrm{O} 3$ & 0.05 & $\mathrm{Cr}$ & 0.02 \\
\hline
\end{tabular}

Among heavy metal concentration, Mercury $(0.13 \%)$ was found more than the WHO permissible limit but lead $(0.04 \%)$ was within the limit (Table 1). Arsenic and Cadmium was below the detectable level of the instrument in AC (Table 1). Moreover, the XRF study report in Table 1 shows the concentration of each element separately but these elements present in the AC were bind with oxygen as oxide form except Mercury which was in elemental form found to be over concentration than the permissible limit. Another study reported that AC has elemental form of Iron $(21 \%)$, Tin $(8.5 \%)$, Mercury $(3.1 \%)$, Lead $(0.04 \%)$ and Copper $(0.03 \%)$ concentration was done on Inductively coupled plasma optical emission spectroscopy study (ICP-OES) (Shibi et al., 2012). The above study showed variations in metallic concentrations in relation to our study. Since the presence of high concentrated elemental mercury in $\mathrm{AC}$, it is essential to screen its toxicity profile even though AC has been used as an analgesic and anti- inflammatory drug in Siddha system of medicine. To validate the therapeutic safety of AC, the acute and sub acute toxicity study was carried out on AC. AC was orally administered at higher dose $2 \mathrm{gm} / \mathrm{kg}$ to the Wistar Albino rats in acute toxicity study and during 28 days of repeated (sub acute) toxicity study, at daily doses of 12, $24 \& 48 \mathrm{mg} / \mathrm{kg}$ of body weight to the Wistar Albino rats. The acute toxicity study showed no mortality of rats up to the dosage of $2000 \mathrm{mg} / \mathrm{kg}$. No behavioural changes or abnormal clinical signs of toxicity were observed up to the above dosage throughout the end of 14 day study period. No gross pathological abnormality in the organs was found even at this high dose. LD50 value was found to be more than $2000 \mathrm{mg} / \mathrm{kg}$ body weight and therefore this test drug Arumuga Chendhuram falls under (Unclassified) category $\mathrm{V}$ with reference to Globally Harmonized classification System (GHS) (OECD, 2000). In this study, the dose of test drug administered in rat was 100 times more than that of the human therapeutic dose. It was clearly proved that the human therapeutic dose was absolutely free from acute toxicity. For a period of 28 consecutive days of oral treatment of AC at 12, $24 \&$ $48 \mathrm{mg} / \mathrm{kg} /$ day in both sexes of rat, no treatment related toxicity signs or mortality were observed. Feed and water consumption of treated groups were found not to be significantly affected or changed in both sexes compared to the distilled water treated rats. Consumption of toxic substances effects at least a minimal reduction in body weight gain and internal organs weight (Teo et al., 2002). During the study, the treated test groups gained weight gradually in respective to the feed intake similar to the control group [Figure 1]. The absolute and relative organs weight was also not altered by AC treatments [Table 2].

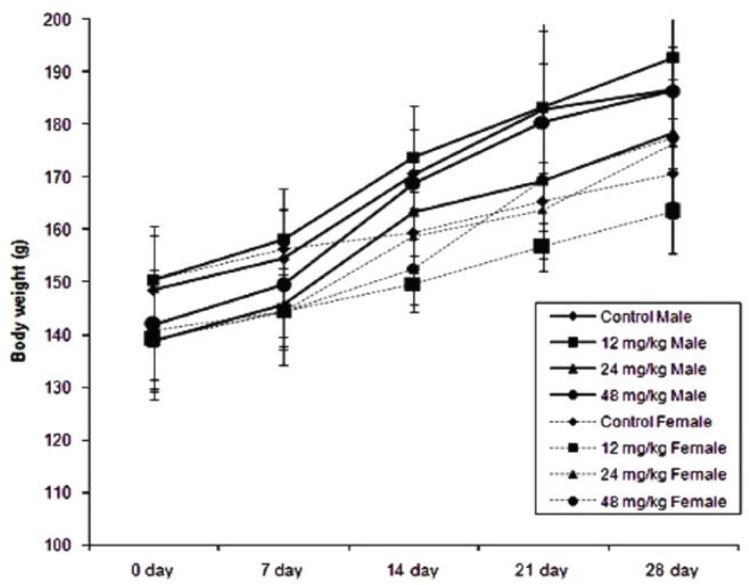

Fig. 1: Effect of Arumuga Chendhuram on body weight in male and female Wistar Albino rats - 28 days repeated oral toxicity study. Values were expressed as mean \pm S.D. $(n=5 /$ group/sex $)$ 
Table 2: Effect of Arumuga Chendhuram on relative organ weight in Wistar Albino rats - 28 days repeated oral toxicity study.

\begin{tabular}{|c|c|c|c|c|}
\hline \multirow{2}{*}{ Organ } & \multirow[t]{2}{*}{ Control } & \multicolumn{3}{|c|}{ Arumuga Chendhuram } \\
\hline & & $12 \mathrm{mg} / \mathrm{kg}$ & $24 \mathrm{mg} / \mathrm{kg}$ & $48 \mathrm{mg} / \mathrm{kg}$ \\
\hline \multicolumn{5}{|l|}{ Male } \\
\hline Brain $(\mathrm{g} \%)$ & $0.98 \pm 0.26$ & $0.96 \pm 0.15$ & $1.06 \pm 0.24$ & $0.98 \pm 0.11$ \\
\hline Heart $(\mathrm{g} \%)$ & $0.40 \pm 0.08$ & $0.42 \pm 0.04$ & $0.40 \pm 0.04$ & $0.38 \pm 0.02$ \\
\hline Liver $(\mathrm{g} \%)$ & $3.52 \pm 0.26$ & $3.71 \pm 0.33$ & $3.98 \pm 1.0$ & $3.62 \pm 1.25$ \\
\hline Spleen $(\mathrm{g} \%)$ & $0.46 \pm 0.04$ & $0.52 \pm 0.17$ & $0.43 \pm 0.15$ & $0.47 \pm 0.08$ \\
\hline Kidney $(\mathrm{g} \%)$ & $0.87 \pm 0.11$ & $0.92 \pm 0.13$ & $0.94 \pm 0.35$ & $0.85 \pm 0.06$ \\
\hline Testis (g\%) & $1.06 \pm 0.31$ & $1.12 \pm 0.26$ & $1.11 \pm 0.35$ & $1.07 \pm 0.31$ \\
\hline \multicolumn{5}{|l|}{ Female } \\
\hline Brain $(\mathrm{g} \%)$ & $1.04 \pm 0.06$ & $1.09 \pm 0.08$ & $1.00 \pm 0.04$ & $1.12 \pm 0.08$ \\
\hline Heart $(\mathrm{g} \%)$ & $0.43 \pm 0.04$ & $0.40 \pm 0.02$ & $0.39 \pm 0.04$ & $0.40 \pm 0.04$ \\
\hline Liver $(\mathrm{g} \%)$ & $4.22 \pm 1.0$ & $3.78 \pm 0.4$ & $3.46 \pm 0.26$ & $3.62 \pm 0.71$ \\
\hline Spleen $(\mathrm{g} \%)$ & $0.48 \pm 0.08$ & $0.43 \pm 0.04$ & $0.38 \pm 0.08$ & $0.51 \pm 0.13$ \\
\hline Kidney (g\%) & $0.78 \pm 0.2$ & $0.85 \pm 0.04$ & $0.76 \pm 0.08$ & $0.84 \pm 0.06$ \\
\hline Ovaries $(\mathrm{g} \%)$ & $0.07 \pm 0.04$ & $0.06 \pm 0.02$ & $0.07 \pm 0.02$ & $0.05 \pm 0.02$ \\
\hline
\end{tabular}

Values were expressed as mean \pm S.D. $(n=5)$. P value was calculated using one way ANOVA followed by Dunnett test.

Table 3: Effect of Arumuga Chendhuram on hematological parameters in male Wistar Albino rats - 28 days repeated oral toxicity study.

\begin{tabular}{|c|c|c|c|c|}
\hline \multirow{2}{*}{ Parameter } & \multirow{2}{*}{ Control } & \multicolumn{3}{|c|}{ Arumuga Chendhuram } \\
\hline & & $12 \mathrm{mg} / \mathrm{kg}$ & $24 \mathrm{mg} / \mathrm{kg}$ & $48 \mathrm{mg} / \mathrm{kg}$ \\
\hline Total WBC $\left(10^{9} / \mathrm{L}\right)$ & $9.6 \pm 2.01$ & $11.02 \pm 5.82$ & $9.58 \pm 2.12$ & $8.84 \pm 5.19$ \\
\hline Lymphocyte $\left(10^{9} / \mathrm{L}\right)$ & $5.06 \pm 0.79$ & $4.18 \pm 1.01$ & $4.64 \pm 1.00$ & $4.14 \pm 1.69$ \\
\hline Monocyte $\left(10^{9} / \mathrm{L}\right)$ & $0.3 \pm 0.12$ & $0.3 \pm 0.14$ & $0.26 \pm 0.09$ & $0.3 \pm 0.14$ \\
\hline Granulocyte $\left(10^{9} / \mathrm{L}\right)$ & $3.62 \pm 0.80$ & $6.24 \pm 5.44$ & $4.68 \pm 1.72$ & $4.4 \pm 3.4$ \\
\hline Hemoglobin (g/dL & $17.5 \pm 2.79$ & $15.38 \pm 3.87$ & $17.08 \pm 1.31$ & $9.54 \pm 4.76^{* *}$ \\
\hline Total RBC $\left(10^{12} / \mathrm{L}\right)$ & $9.89 \pm 1.51$ & $9.40 \pm 2.37$ & $10.06 \pm 0.90$ & $5.71 \pm 2.74^{*}$ \\
\hline RDW $(\%)$ & $11.4 \pm 1.24$ & $12.6 \pm 2.23$ & $11.44 \pm 0.55$ & $11.18 \pm 0.64$ \\
\hline Hematocrit (\%) & $51.7 \pm 8.50$ & $47.16 \pm 11.75$ & $51.66 \pm 4.22$ & $27.94 \pm 13.62^{* *}$ \\
\hline MCV (fL) & $52.36 \pm 0.89$ & $50.2 \pm 2.16^{*}$ & $51.46 \pm 0.45$ & $48.96 \pm 0.60^{* *}$ \\
\hline $\mathrm{MCH}(\mathrm{pg})$ & $17.6 \pm 0.46$ & $16.3 \pm 0.85^{*}$ & $16.96 \pm 0.43$ & $16.5 \pm 0.60^{*}$ \\
\hline $\mathrm{MCHC}(\mathrm{g} / \mathrm{dL})$ & $33.8 \pm 0.60$ & $32.54 \pm 0.55^{*}$ & $33.04 \pm 0.65$ & $33.9 \pm 0.80$ \\
\hline Platelet $\left(10^{9} / \mathrm{L}\right)$ & $96.4 \pm 33.5$ & $86.6 \pm 28.9$ & $79.0 \pm 17.65$ & $87.8 \pm 23.0$ \\
\hline Platelet crit (\%) & $0.05 \pm 0.02$ & $0.05 \pm 0.02$ & $0.05 \pm 0.01$ & $0.05 \pm 0.01$ \\
\hline PDW (\%) & $15.3 \pm 0.19$ & $15.8 \pm 1.57$ & $15.4 \pm 0.34$ & $15.1 \pm 0.15$ \\
\hline MPV(fL) & $6.16 \pm 0.19$ & $5.92 \pm 0.49$ & $6.04 \pm 0.19$ & $5.86 \pm 0.11$ \\
\hline
\end{tabular}

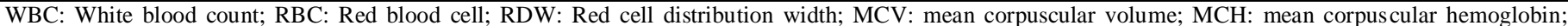

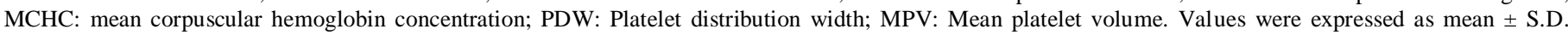
$(\mathrm{n}=5)$. $\mathrm{P}$ value was calculated using one way ANOVA followed by Dunnett test. Significance was indicated as $* \mathrm{p}<0.05$ and $* * \mathrm{p}<0.01$ vs. control group.

If $\mathrm{AC}$ were a toxic substance, there would have been a minimal reduction in body weight gain and internal organs weight. The changes observed in blood parameters analysed in laboratory animals provide the evidence of risk of toxic effects on haematological system (Olsan et al., 2000). The hematological profile of the treated and control groups were presented in the Table 3 \& 4. White blood cell parameters tested such as Lymphocytes, Monocytes and Granulocytes in both male and female rats showed no significant differences in relation to the control group. In male groups, $\mathrm{AC}$ at $48 \mathrm{mg} / \mathrm{kg}$ (high dose) induced to decrease the values of $\mathrm{Hb}, \mathrm{RBC}$ count, HCT and MCV in relation to the control group. $\mathrm{MCH}$ value was decreased significantly in both AC treated low dose $(12 \mathrm{mg} / \mathrm{kg})$ and high dose $(48 \mathrm{mg} / \mathrm{kg}$ ). Administration of $\mathrm{AC}$ at $24 \mathrm{mg} / \mathrm{kg}$ (Intermittent dose) in relation to the control male group, no statistically significant changes was noted in the haematological parameters analysed. But in female rats, treated with $\mathrm{AC}$ at three doses compared with control group, no statistically significant difference was recorded in any of the haematological parameters examined. Haematopoiesis is the process of formation of blood cellular components which includes leukopoiesis stage i.e. the formation of white blood cells in bone marrow (adults) and haematopoietic organs (foetus) (Evan, 2008). However, the significant differences noted in the parameters at high and low dose groups lies within normal physiological limits indicated that $\mathrm{AC}$ did not affect haematopoiesis or leukopoiesis in rats and that suggested AC did not produce any toxicity in the blood forming organs affecting the haematopoietic indices.

The biochemical profiles of the treated group were presented in the table $5 \& 6$. Estimation of SGOT, SGPT, Bilirubin and ALP levels are the useful indicators of hepatic function and Protein, Urea, Creatinine and electrolytes such as Sodium, Potassium and Chlorides are the useful indicators of renal function. The glucose and cholesterol level showed significant increase treated at the dose $24 \mathrm{mg} / \mathrm{kg}$ (Intermittent dose) in both male and female rats compared with control and is due to variation in animals. The hepatic enzyme SGOT showed a significant increase in female rats treated at low dose $(12 \mathrm{mg} / \mathrm{kg})$ but SGPT showed no significant changes in both male and female rats. The increased levels of both SGOT and SGPT in the blood are associated with injury of hepatocytes (Burger et al., 2005 and Witthawaskul et al., 2003). Increased levels of ALP and Bilirubin more than a fold indicate the damage on biliary tract associated with intrahepatic bile ductules (Sacher and McPherson, 1991). 
Table 4: Effect of Arumuga Chendhuram on hematological parameters in female Wistar Albino rats - 28 days repeated oral toxicity study.

\begin{tabular}{|c|c|c|c|c|}
\hline \multirow{2}{*}{ Parameter } & \multirow{2}{*}{ Control } & \multicolumn{3}{|c|}{ Arumuga Chendhuram } \\
\hline & & $12 \mathrm{mg} / \mathrm{kg}$ & $24 \mathrm{mg} / \mathrm{kg}$ & $48 \mathrm{mg} / \mathrm{kg}$ \\
\hline Total WBC $\left(10^{9} / \mathrm{L}\right)$ & $7.34 \pm 2.94$ & $7.22 \pm 2.07$ & $5.74 \pm 2.49$ & $6.48 \pm 1.86$ \\
\hline Lymphocyte $\left(10^{9} / \mathrm{L}\right)$ & $4.08 \pm 1.56$ & $3.86 \pm 0.95$ & $3.22 \pm 0.94$ & $3.96 \pm 1.34$ \\
\hline Monocyte $\left(10^{9} / \mathrm{L}\right)$ & $0.28 \pm 0.14$ & $0.2 \pm 0.07$ & $0.16 \pm 0.09$ & $0.18 \pm 0.04$ \\
\hline Granulocyte $\left(10^{9} / \mathrm{L}\right)$ & $3.6 \pm 2.2$ & $3.12 \pm 1.20$ & $2.36 \pm 1.58$ & $2.38 \pm 0.61$ \\
\hline Hemoglobin (g/dL) & $13.9 \pm 4.13$ & $18.48 \quad \pm 2.32$ & $11.04 \pm 4.71$ & $10.38 \pm 2.90$ \\
\hline Total RBC $\left(10^{12} / \mathrm{L}\right)$ & $7.99 \pm 2.18$ & $10.70 \pm 1.30$ & $6.49 \pm 2.68$ & $6.03 \pm 1.50$ \\
\hline RDW (\%) & $10.02 \pm 0.8$ & $10.38 \pm 0.65$ & $10.44 \pm 0.96$ & $10.24 \pm 0.38$ \\
\hline Hematocrit (\%) & $42.5 \pm 13.7$ & $54.88 \pm 6.52$ & $33.52 \pm 14.27$ & $30.62 \pm 7.80$ \\
\hline $\operatorname{MCV}(\mathrm{fL})$ & $52.6 \pm 3.28$ & $51.38 \pm 1.01$ & $51.5 \pm 1.62$ & $50.86 \pm 1.54$ \\
\hline $\mathrm{MCH}(\mathrm{pg})$ & $17.3 \pm 0.62$ & $17.22 \pm 0.15$ & $16.88 \pm 0.89$ & $17.08 \pm 0.78$ \\
\hline $\mathrm{MCHC}(\mathrm{g} / \mathrm{dL})$ & $33.08 \pm 1.2$ & $33.6 \pm 0.53$ & $32.84 \pm 0.76$ & $33.7 \pm 0.98$ \\
\hline Platelet $\left(10^{9} / \mathrm{L}\right)$ & $83.4 \pm 18.6$ & $78.6 \pm 27.40$ & $80.6 \pm 30.25$ & $70.8 \pm 24.74$ \\
\hline Platelet crit (\%) & $0.05 \pm 0.0$ & $0.05 \pm 0.02$ & $0.05 \pm 0.01$ & $0.04 \pm 0.01$ \\
\hline PDW (\%) & $15.42 \pm 0.43$ & $15.58 \pm 0.30$ & $15.7 \pm 0.38$ & $15.26 \pm 0.27$ \\
\hline MPV(fL) & $6.22 \pm 0.36$ & $6.5 \pm 0.14$ & $6.3 \pm 0.29$ & $6.06 \pm 027$ \\
\hline
\end{tabular}

WBC: White blood count; RBC: Red blood cell; RDW: Red cell distribution width; MCV: mean corpuscular volume; MCH: mean corpuscular hemoglobin; MCHC: mean corpuscular hemoglobin concentration; PDW: Platelet distribution width; MPV: Mean platelet volume. Values were expressed as mean \pm S.D. $(\mathrm{n}=$

5). $P$ value was calculated using one way ANOVA followed by Dunnett test.

Table 5: Effect of Arumuga Chendhuram on biochemical parameters in male Wistar Albino rats - 28 days repeated oral toxicity study.

\begin{tabular}{|c|c|c|c|c|}
\hline \multirow[t]{2}{*}{ Parameter } & \multirow[t]{2}{*}{ Control } & \multicolumn{3}{|c|}{ Arumuga chendhuram } \\
\hline & & $12 \mathrm{mg} / \mathrm{kg}$ & $24 \mathrm{mg} / \mathrm{kg}$ & $48 \mathrm{mg} / \mathrm{kg}$ \\
\hline Glucose (mg/dl) & $72.6 \pm 11.71$ & $83.2 \pm 10.73$ & $91.2 \pm 7.08^{*}$ & $72.0 \pm 6.59$ \\
\hline Cholesterol (mg/dl) & $1.18 \pm 0.13$ & $1.32 \pm 0.10$ & $1.04 \pm 0.20$ & $1.1 \pm 0.1$ \\
\hline Triglyceride (U/L) & $72.6 \pm 16.31$ & $54.0 \pm 15.47$ & $72.8 \pm 3.63$ & $74.6 \pm 16.87$ \\
\hline Protein (g/dL) & $6.8 \pm 0.08$ & $7.2 \pm 0.56$ & $7.18 \pm 0.71$ & $7.2 \pm 0.81$ \\
\hline Urea $(\mathrm{mg} / \mathrm{dl})$ & $42.8 \pm 1.92$ & $42.2 \pm 6.26$ & $37.0 \pm 4.89$ & $30.4 \pm 3.64^{* *}$ \\
\hline Creatinine $(\mathrm{mg} / \mathrm{dl})$ & $1.18 \pm 0.13$ & $1.32 \pm 0.10$ & $1.04 \pm 0.20$ & $1.1 \pm 0.1$ \\
\hline Bilirubin $(\mathrm{mg} / \mathrm{dl})$ & $0.38 \pm 0.08$ & $0.56 \pm 0.11$ & $0.52 \pm 0.19$ & $0.68 \pm 0.13^{* *}$ \\
\hline SGOT (U/L) & $201.4 \pm 43.52$ & $181.4 \pm 36.65$ & $151.0 \pm 35.98$ & $150.6 \pm 35.9$ \\
\hline SGPT (U/L) & $86.4 \pm 20.0$ & $79.2 \pm 11.84$ & $84.6 \pm 10.64$ & $81.2 \pm 8.89$ \\
\hline ALP(U/L) & $429.8 \pm 36.8$ & $370.6 \pm 41.27$ & $375.6 \pm 49.6$ & $331.6 \pm 52.56^{* *}$ \\
\hline Sodium $(\mathrm{mmol} / \mathrm{L})$ & $144.0 \pm 5.43$ & $139.2 \pm 7.5$ & $136.2 \pm 15.49$ & $142.8 \pm 10.54$ \\
\hline Potassium (mmol/L) & $4.6 \pm 1.3$ & $5.24 \pm 2.52$ & $4.24 \pm 1.41$ & $5.1 \pm 1.02$ \\
\hline Chloride (mmol/L) & $104.6 \pm 4.22$ & $113.4 \pm 11.9$ & $106.8 \pm 7.49$ & $111.6 \pm 10.36$ \\
\hline
\end{tabular}

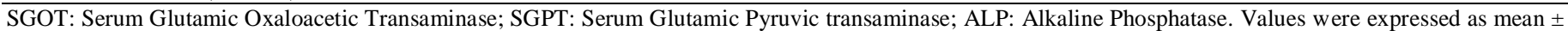
S.D. $(n=5)$. P value was calculated using one way ANOVA followed by Dunnett test. Significance was indicated as *p < 0.05 and $* * p<0.01$ vs. control group.

Table 6: Effect of Arumuga Chendhuram on biochemical parameters in female Wistar Albino rats - 28 days repeated oral toxicity study.

\begin{tabular}{|c|c|c|c|c|}
\hline \multirow[t]{2}{*}{ Parameter } & \multirow[t]{2}{*}{ Control } & \multicolumn{3}{|c|}{ Arumuga Chendhuram } \\
\hline & & $12 \mathrm{mg} / \mathrm{kg}$ & $24 \mathrm{mg} / \mathrm{kg}$ & $48 \mathrm{mg} / \mathrm{kg}$ \\
\hline Glucose (mg/dl) & $87.6 \pm 10.62$ & $74.8 \pm 7.32$ & $86.0 \pm 16.17$ & $80.6 \pm 7.82$ \\
\hline Cholesterol (mg/dl) & $66.6 \pm 8.35$ & $67.2 \pm 13.7$ & $101.2 \pm 10.56^{* *}$ & $67.6 \pm 7.16$ \\
\hline Triglyceride (U/L) & $179.6 \pm 26.65$ & $196.2 \pm 50.83$ & $178.8 \pm 115.94$ & $156.6 \pm 51.69$ \\
\hline Protein (g/dL) & $7.02 \pm 0.82$ & $6.82 \pm 0.74$ & $7.22 \pm 0.98$ & $7.02 \pm 0.88$ \\
\hline Urea (mg/dl) & $45.8 \pm 2.77$ & $37.0 \pm 7.51$ & $40.4 \pm 6.42$ & $39.8 \pm 5.54$ \\
\hline Creatinine (mg/dl) & $1.26 \pm 0.08$ & $1.54 \pm 0.27$ & $1.1 \pm 0.1$ & $1.12 \pm 0.13$ \\
\hline Bilirubin (mg/dl) & $0.62 \pm 0.13$ & $0.48 \pm 0.08$ & $0.66 \pm 0.11$ & $0.68 \pm 0.10$ \\
\hline SGOT (U/L) & $125.2 \pm 14.93$ & $178.0 \pm 29.56^{*}$ & $155.0 \pm 31.67$ & $127.0 \pm 33.63$ \\
\hline SGPT (U/L) & $66.6 \pm 15.99$ & $80.8 \pm 22.32$ & $66.8 \pm 8.46$ & $56.6 \pm 18.48$ \\
\hline ALP(U/L) & $353.6 \pm 63.8$ & $308.8 \pm 21.65$ & $363.2 \pm 68.81$ & $326.0 \pm 29.40$ \\
\hline Sodium (mmol/L) & $145.0 \pm 5.29$ & $144.6 \pm 12.86$ & $135.6 \pm 15.58$ & $143.6 \pm 6.73$ \\
\hline Potassium (mmol/L) & $3.96 \pm 1.76$ & $5.0 \pm 0.98$ & $3.8 \pm 1.66$ & $4.88 \pm 1.31$ \\
\hline Chloride (mmol/L) & $105.0 \pm 5.09$ & $108.4 \pm 10.59$ & $109.4 \pm 7.43$ & $107.6 \pm 8.79$ \\
\hline
\end{tabular}

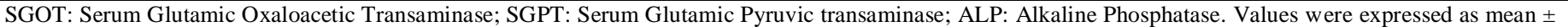
S.D. $(\mathrm{n}=5)$. P value was calculated using one way ANOVA followed by Dunnett test. Significance was indicated as $* \mathrm{p}<0.05$ and $* * \mathrm{p}<0.01$ vs. control group.

Here, ALP was significantly decreased in male rats of low dose $(12 \mathrm{mg} / \mathrm{kg})$ and high dose $(48 \mathrm{mg} / \mathrm{kg})$ groups respectively and in contrast bilirubin was significantly increased in high dose group. Among renal parameters tested in male rats, urea level was significantly decreased treated at high dose $(48 \mathrm{mg} / \mathrm{kg})$ and also in female rats treated at low dose $(12 \mathrm{mg} / \mathrm{kg})$ groups in relation to the control group but creatinine showed no significant changes in both sex at three dosages. In hepatic disorders, the mentioned parameters would rise to more than one fold of their value and in renal disorders; the parameters would rise over their normal limits (Rebecca et al., 2002). High Cholesterol is an indirect marker to access the variations in liver function (Hilaly et al., 2004). Among 
female rats, cholesterol level was found to be increased significantly in intermittent dose group $(24 \mathrm{mg} / \mathrm{kg})$. In both male and female rats, there were no significant differences in biochemical parameters such as Triglycerides, Protein, Creatinine, SGPT, Sodium, Potassium and Chlorides were observed at three doses compared to the control group. Moreover, the statistically significant changes noted in the biochemical parameters lay within the normal physiological limits which favours AC as a safer drug during metabolism and did not cause any major pathological lesions in vital organs.
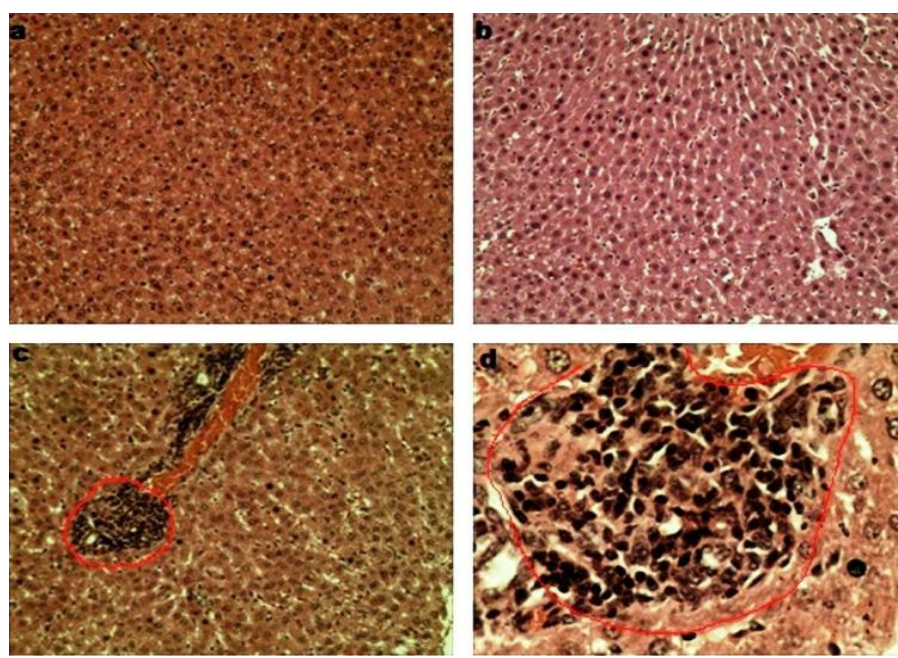

Fig. 2: H\&E stained liver slices of rats done for 28 days repeated oral toxicity study of Arumuga Chendhuram (AC). (a) Liver slices of control and (b) 48 $\mathrm{mg} / \mathrm{kg}$ AC treated male rat had normal architecture (x100). (c) Liver slice of female rats treated with $48 \mathrm{mg} / \mathrm{kg} \mathrm{AC}$ at x100 and (d) at x400 magnifications showed mononuclear cells infiltration.

This was further confirmed by the gross necropsy studies that had been on the organs which revealed no abnormal pathological morphology. H\&E stained liver slices of female rats of high dose group showed changes in their architecture by the presence of minimal infiltration of mononuclear cells indicated slight inflammation of hepatocytes [Figure $2-\mathrm{c}$, d]. But, in the liver of male rats, no evidence of such lesions was observed [Figure 2 - b]. Generally, mononuclear cell infiltrations of liver had been seen in one third of the normal laboratory rats (Shayne, 2007) and it is not due to the involvement of myelogenous origin (Zawidska, 1971). We inferred that this infiltration of mononuclear cell is not the sign of treatment related toxicity. Further, in the Haematological and Eosin stained slices of Kidney, Lungs, Heart, Spleen, Stomach, Brain and Femoro-tibial joint, there were no treatment related histopathological abnormalities seen and so their images were not presented here. From the results of haematological, biochemical and histopathological analyses, we inferred that $\mathrm{AC}$ at high dose $(48 \mathrm{mg} / \mathrm{kg})$ produced statistically significant variations in relation to the control group and LowObserved-Adverse-Effect level (LOAEL) were seen at high dose $48 \mathrm{mg} / \mathrm{kg} /$ day. The high dose of AC employed in this study was ten times more than the dose employed in humans for therapy. Moreover, the oral intermittent dose $24 \mathrm{mg} / \mathrm{kg} /$ day of $\mathrm{AC}$ administered for 28 consecutive days did not induce any biochemical, haematological, anatomical and histopathological signs of toxicity and the above dose can be defined as the NoObserved-Adverse-Effect level (NOAEL) for both the sexes under the experimental conditions used.

\section{CONCLUSION}

The analyses of data suggests that the oral administration of Arumuga chendhuram did not induce any toxic effect at 24 $\mathrm{mg} / \mathrm{kg} / \mathrm{day}$ dose in rats, and this stands as an assurance of safe usage at its desirable human intended therapeutic dosage of 260 $\mathrm{mg} / 70 \mathrm{~kg} /$ day in the practice of Siddha medicine.

\section{ACKNOWLEDGEMENT}

The authors wish to thank Vice Chancellor of The Tamil Nadu Dr. MGR Medical University, Chennai and Director of National Institute of Siddha for their support.

\section{REFERENCES}

Abbott P, Prentice DE, Cherry CP. Mononuclear Cell Leukemia in Aged Sprague-Dawley Rats D. Veterinary Pathology, 1983; 20:434439.

Anaivaari R Anadhan. 2008. Siddha Materia Medica (Mineral \& Animal Sections). Chennai, India: Department of Indian Medicine and Homoeopathy.

Burger C, Fischer DR, Cordenunzzi DA, Batschauer AP, Cechinel Filho V, Soares AR. Acute and subacute toxicity of the hydroalcoholic extract from Wedelia paludosa (Acmela brasiliensis) (Asteraceae) in mice. Journal of Pharmacy \& Pharmaceutical Sciences, 2005; 8:370-373.

Evan GO. 2008. Animal Hematotoxicology: A Practical Guide for Toxicologists and Biomedical Researchers. Boca Raton, CRC Press.

Hilaly JE, Israili ZH, Lyoussi B. Acute and chronic toxicological studies of Ajuga iva in experimental animals. Journal of Ethnopharmacology, 2004; 91:43-50.

Kapoor RC. Some observations on the metal based preparation in the Indian system of Medicine. Indian Journal of Traditional Knowledge, 2010; 9:562-575.

Kuppusamy Mudhaliar KN, Utthamarayan KS. 1998. Siddha Vaithiya Thirattu. Chennai, India: Department of Indian Medicine and Homoeopathy.

OECD. Guideline Number 423 for the Testing of Chemicals: Revised Draft Guideline 423 (Acute Oral Toxicity). Paris, France: OECD; 2000.

OECD. Guideline Number 407 for the Testing of Chemicals: Repeated Dose 28 day Oral Toxicity Study in Rodents. Paris, France: OECD; 2008.

Olson H, Betton G, Robinson D, Thomas K, Monro A, Kolaja $\mathrm{G}$, et al. Concordance of toxicity of pharmaceuticals in humans and in animals. Regulatory Toxicology and Pharmacology, 2000; 32:5667.

Paget GE, Barnes JM. 1964. Toxicity tests. In: Laurance DR, Bacharach AL, ed. Evaluation of Drug Activities: Pharmacometrics. Vol. 1. New York: Academic Press 135-65.

Rebecca MA, Ishii Iwamoto EL, Grespan R, Cuman RK, Caparroz Assef SM, Mello JC, Bersani Amado CA. Toxicological studies on Stryphnodendron adstringens. Journal of Ethnopharmacology, 2002; 83:101-104.

Sacher RA, McPherson RA. 1991. Test of liver function. In: Widmann's Clinical Interpretation of Laboratory Test. Philadelphia: FA Davis Company. pp. 416-43. 

CRC Press.

Shayne C Gad. 2007. Animal Models in Toxicology. Florida:

Shibi IG, Shalu G, Jagannathan K. Physico Chemical Analysis of Arumuga Chendooram. International Journal of Research in Ayurveda and Pharmacy, 2012; 3:433-438.

Singh UB, Sulochana S. 1997. Handbook of Histological and Histochemical Techniques. Hyderabad, India: Premier Publishing House.

Teo S, Strlig D, Thomas S, Hoberman A, Kiorpes A, Khetani V. A 90 days oral gavage toxicity study of d-methylphenidate and d,1methylphenidate in Sprague Dawley rats. Toxicology, 2002; 79:183-196.

Witthawaskul P, Panthong A, Kanjanapothi D, Taesothikul T, Lertprasertsuke N. Acute and subacute toxicities of the saponin mixture isolated from Schefflera leucantha Viguier. Journal of Ethnopharmacology, 2003; 89:115-121.
Zawidska ZZ, Grice HG. Alterations in morphology and growth pattern in a transplantable leukemia of rats. Cancer Research, 1971; $31: 1990-1998$

\section{How to cite this article:}

Murugan R, Vembu T, Kumarswamy M. Toxicological Study of a Siddha Sastric Formulation Arumuga Chendhuram in Rat Model. J App Pharm Sci, 2016; 6 (03): 081-087. 